\title{
Optimal management of Cushing syndrome
}

This article was published in the following Dove Press journal:

Research and Reports in Endocrine Disorders

20 June 2012

Number of times this article has been viewed

Edgar G Durán-Pérez'

Oscar T Moreno-Loza ${ }^{2}$

German Carrasco-Tobón ${ }^{3}$

Antonio Segovia-Palomo ${ }^{3}$

'Division of Endocrinology, Hospital General de Saltillo, Saltillo, Coahuila, ${ }^{2}$ Division of Endocrinology, Hospital de Alta Especialidad, ISSSTE, Tultitlán, ${ }^{3}$ Endocrinology Deparment, Hospital General de México, México Distrito Federal, México
Correspondence: Edgar G Durán-Pérez Blvd.V. Carranza \#4036, col. Villa

Olimpica, Zip Code 25230, Saltillo

Coahuila, Mexico

Tel +52 8444390607

Fax +52 8444390607

Email edurandr@gmail.com
Abstract: Cushing syndrome (CS) caused by endogenous hypercortisolism is a diagnostic challenge. The most common cause is Cushing disease. Surgical treatment is the first-line therapy for Cushing disease. However, due to the often clinical instability of the patient's condition, which needs acute treatment of hypercortisolism or inoperable tumors, initial surgery is often not possible. It is therefore important to provide appropriate initial medical treatment. Following surgery, the patient needs to be evaluated and confirmed for disease resolution based on standard criteria, and treated with appropriate supportive measures for the rest of life if necessary. This article reviews the current data and treatment options for Cushing syndrome and proposes a therapeutic algorithm for its optimal management.

Keywords: cushing syndrome, cushing disease, hypercortisolism

\section{Introduction}

Cushing syndrome (CS) occurs as a result of long and chronic exposure to glucocorticoids (GCs). The most common cause is exogenous CS secondary to GC intake. ${ }^{1,2}$ Endogenous CS is more common in women. Its occurrence is from about 0.7 to 2.4 per 1 million population by year. ${ }^{3}$

GCs are synthetic steroids that are effective in the management of inflammatory, allergic, hematologic, and autoimmune processes, among others. Due to their remarkable anti-inflammatory effect and secondary pain reduction with rapid improvement of symptoms, the use of these drugs leads the patient to an indiscriminate intake and thus to side effects. ${ }^{4,5}$

Patients with noncontrolled CS have a five-fold increase in mortality. ${ }^{6}$ The screening studies performed in diabetic patients, especially in those diabetic patients with difficult control and with obesity and hypertension, suggest that it has a prevalence of $2 \%-5 \%{ }^{7}$

The present review aims to expose the "optimal" treatment options for CS, briefly stating the causes and offering a description of CS management induced by GCs.

Endogenous CS occurs in $80 \%-85 \%$ of the cases due to corticotropin (ACTH)dependent causes: $80 \%$ is due to pituitary tumors (Cushing disease [CD]), and the remaining $20 \%$ is secondary to ectopic secretion of $\mathrm{ACTH}$, which usually derives from carcinoid tumors or small-cell lung carcinoma.

ACTH-independent CS occurs in 15\%-20\% of cases, and most of these are caused by an adrenal tumor (adenoma or cancer, $75 \%$ ) or, more rarely, macronodular adrenal hyperplasia and pigmented nodular adrenal disease. ${ }^{1,6,8-10}$ The diagnosis of endogenous 
$\mathrm{CS}$ is a challenge; thus, this review does not cover such a target and is reserved only for treatment. For diagnosis it is worth consulting clinical guides. ${ }^{11}$

\section{Exogenous CS and its treatment}

Exogenous CS occurs due to an excess of and chronic exposure to synthetic GCs, which suppress the synthesis and secretion of hypothalamic ACTH-releasing factor and therefore of ACTH, producing bilateral atrophy of adrenal glands and a decrease of endogenous cortisol. ${ }^{12}$ The use of prednisone at high doses over 5 days diminishes the weight of the adrenal gland, although it depends upon the dose and overall time in which it has been used. Prednisone administration from $20 \mathrm{mg}$ to $30 \mathrm{mg}$ over 7 days or more inhibits the hypothalamic-pituitary-adrenal axis (HPA). At a low dose (less than $7.5 \mathrm{mg} /$ day), it may suppress the HPA axis in a 1-month interval. ${ }^{13,14}$

Recovery of the HPA axis after suspension of the medicament may follow four stages: (1) stage I: a month after suspending GC, the ACTH is low and the plasmatic and urinary 17-hydroxicorticosteroids (17OHC) are low; (2) stage II: from 2 to 5 months after suspension of the medicament, the ACTH is normal but $17-\mathrm{OHC}$ is low and without incurring response to ACTH stimulation; (3) stage III: from 6 to 9 months after suspension, the ACTH is normal and the plasmatic and urinary 17-OHC are normal but incurring an abnormal adrenal response to ACTH stimulation; and (4) stage IV: from 9 to 12 months after suspension, a complete recovery of the HPA axis is achieved. ${ }^{14,15}$ LaRochelle et al ${ }^{16}$ found in patients with rheumatologic disorders and receiving low doses of prednisone that lower doses of $5 \mathrm{mg}$ per day had a normal HPA axis independently from evolution time, while those with a higher dose of $5 \mathrm{mg}$ per day had a greater inhibition frequency of the HPA axis.

The diagnosis is established with the clinical manifestations, in addition to the background of GC therapy. Later on, suppressed endogenous cortisol levels and low ACTH levels are expected to be found. ${ }^{4,12}$ The specific clinical features of hypercortisolism may differ in terms of intensity depending upon the CS cause, either endogenous or due to GC intake. ${ }^{17}$

The use of GC is very common; nonetheless, there is not enough evidence detailing suspension or withdrawal of steroids. ${ }^{18}$ The aim for decreasing or suspending GC is firstly based on achieving a GC decrease, which has been used in physiologic doses, and at the same time preventing the patient from onset of a suprarenal crisis. An option is decreasing the dose $10 \%-20 \%$ every 2 weeks. Therefore, as a first step after reduction of the steroid, we propose giving physiological doses (15-20 mg/day of hydrocortisone or 5-7.5 mg/day of prednisone). ${ }^{19}$ Afterwards, changing to an early morning dose of hydrocortisone or prednisone or even one dose every 48 hours allows a gradual recovery of HPA axis. ${ }^{20}$

The greater risk of suspending GC consists of an adrenal crisis development, or by avoiding it by means of a gradual dose decrease of GC the risk will be the exacerbation of the underlying disease that in the first instance forced the prescription of GC.

The next stage is measuring the early morning serum cortisol levels (8:00 AM), wherein a serum level less than $3 \mathrm{mcg} / \mathrm{dL}$ would indicate cortisol deficiency rather than HPA axis recovery, being necessary to continue with replacement therapy. A serum cortisol level between $3 \mathrm{mcg} / \mathrm{dL}$ and $20 \mathrm{mcg} / \mathrm{dL}$ indicates that the patient has a basal cortisol secretion but lacks the capability of responding to physiological stress. When this occurs, an ACTH (Synacthen) stimulation test is recommended, or an insulin tolerance test for examining the capability response of adrenal glands and thus from the HPA axis. If serum cortisol levels are greater than $20 \mathrm{mcg} / \mathrm{dL}$, then it can be assumed that the patient has recovered the HPA axis and therefore GC therapy can be withdrawn. ${ }^{19}$

We will describe here the endogenous CS-specific treatment and its several causes, as well as the remission criteria for hypercortisolism.

\section{Surgical treatment of CS}

Because the main cause of endogenous hypercortisolism is ACTH-dependent (80\%-85\%), which is the most common cause of CD (hypophyseal hypersecretion by a corticotropic adenoma), we describe here some surgical treatment considerations. ${ }^{21,22}$

\section{Transsphenoidal surgery}

For more than 3 decades transsphenoidal surgery (TSS) has been the best option for patients suffering from CD. Adenectomy was disclosed and performed by Hardy in the 1960 s. $^{23}$ Since then the technique has been improved, and selective adenomectomies have been possible. A problem we face is that many centers discuss their experiences in-house without satisfactorily documenting the healing and recurrence rates, although many of these reports show similar percentages.

Some classic studies that were performed in the 1960 s report a remission rate within an interval from $50 \%-90 \% .^{25-27}$ After TSS, the overall recurrence rate 
(micro- or macroadenoma) can be considered to be from about $3 \%$ to $17 \%$ and mortality up to $1.9 \% .^{21}$

Only 5\%-20\% of ACTH-producing adenomas are macroadenomas $(>10 \mathrm{~mm})$. Thus, the healing and recurrence may be due to this important factor. Most macroadenomas have a bad postsurgical prognosis. Some studies have disclosed remission ranging from $53 \%$ to $68 \%,{ }^{28}$ and others point out lower rates of $33 \% .^{29}$ Fomekong et $\mathrm{al}^{28}$ report remission up to $92 \%$, explaining that a noninvasive tumor of the cavernous sinuses with a size less than $15 \mathrm{~mm}$ may be a factor for an improved prognosis. Likewise, Rees et $\mathrm{al}^{30}$ indicate that tumor size has an influence as a healing predictor, independently of the ACTH serum levels. Another factor that appears to confer a favorable prognosis, in addition to adenoma characterization by means of image studies, is histologic identification by immunostaining of ACTH. ${ }^{31}$ This makes sense because postsurgical identification of the said tumor increases remission probability.

Apparently, if we compare the type of surgical technique used, namely adenectomy (extraction of the adenoma only) versus hypophysectomy (resection of almost all the pituitary gland), there is no change regarding remission, but hypophyseal failure is more frequent in hypophysectomy (from $79 \%$ to $95 \%$ ). ${ }^{23}$ The extent of hypopituitarism is $48 \%$, excluding isolated ACTH deficiency, requiring up to $63 \%$ of the patients to temporarily receive hormone replacement therapy including GCs. ${ }^{32}$

According to different series, recurrence fluctuates between $3 \%$ and $17 \%$, with an average of $9.4 \%$ and with variable intervals between 1.5 years and 8 years from the first surgery. Nevertheless, recurrences up to 12.5 years have been disclosed. ${ }^{31}$ In a recent report, overall recurrence rate was $12 \%$ at $4.2 \pm 0.5$ years after surgery. ${ }^{33}$ Remission rates after TSS are variable and depend principally upon tumor extent, the experience of the neurosurgeon, and the used biochemical criterion for its definition. Recently, it has been pointed out that postsurgical cortisol less than $2 \mu \mathrm{g} / \mathrm{dL}$ predicts long-term remission after TSS in CD. ${ }^{33}$ Remission in those with cortisol values $2-4.9 \mu \mathrm{g} / \mathrm{dL}$ at $3-5$ days after surgery suggests that these patients do not require immediate surgical reintervention. ${ }^{33}$ However, all patients require long-term clinical follow-up because no cortisol limit value excludes patients from recurrence. With the aim of obtaining a more objective cortisol serum level and thus define remission of $\mathrm{CD}$, we recommend the use of sensitive tests for postsurgical serum cortisol measurement.

Current standards of follow-up after hypophysis surgery in patients with $\mathrm{CD}$ consider obtaining a morning serum cortisol level $<5 \mu \mathrm{g} / \mathrm{dL}$ as the best criterion for defining remission. ${ }^{1,2,34}$ A lower level does not necessarily relate to lower rates of recurrence. We suggest using urinary free cortisol (UFC) or morning serum cortisol suppression $(<2.4 \mu \mathrm{g} / \mathrm{dL})$ after $1 \mathrm{mg}$ of dexamethasone the previous night. UFC levels with a value less than $20 \mu \mathrm{g} / 24$ hours (by means of ultrasensitive tests) predict remission, while normal or greater values are mistaken to suggest persistence. Following hypophysis surgery it will be necessary to regularly monitor all patients with $\mathrm{CD}$, because there is no absolute cortisol value that predicts remission in $100 \%$ of cases.

Several methods have been used for evaluating prolonged remission of $\mathrm{CD}$, namely overnight dexamethasone suppression test with a $1 \mathrm{mg}$ dose and UFC and ACTH levels. Chen et $\mathrm{al}^{35}$ point out that less than $3 \mu \mathrm{g} / \mathrm{dL}$ of serum cortisol at day 3 after a $1 \mathrm{mg}$ dose of dexamethasone overnight predicts $93 \%$ remission of the patients.

If there are no remission criteria and the surgical procedure was unsuccessful, treatment options include: (1) surgical reintervention, (2) radiotherapy (RT), (3) pharmacological treatment, (4) bilateral adrenalectomy (BA), and (5) a combination thereof. We recommend follow-up remission and regular base monitoring for life.

Mortality for TSS is $0.7 \%$, with complications up to $42 \%$ disclosed. Thirty percent of the patients may present one or more postsurgical complications. Diabetes insipidus and hydroelectrolytic disorders (from 10\%-15\% and from $8.8 \%-12.5 \%$, respectively) are the two most common transitory complications. ${ }^{36,37}$

Patients with corticotropic adenomas appear to have more postsurgical complications of bleeding or neurological disorders compared with other hypophyseal tumors (5.6\% vs $2.6 \%$, respectively), showing greater risk within the first 3 days after surgery; thus, monitoring should be emphasized during this time by early identification of disturbances impacting final prognosis. ${ }^{36}$ Other reported complications are thromboembolic disease, infection, transient paralysis of cranial nerves III, IV, and VI, and epistaxis, all with a range less than $1 \%$. A direct relationship between the number of annual procedures and the number of complications has been noted. Based on the aforementioned, an experienced surgeon has a greater rate of success and fewer complications. ${ }^{37}$

Following an unsuccessful first surgery, early reintervention within the first 60 days has a 38\%-67\% possibility of success. ${ }^{23}$ A second intervention increases the risk of complications, mainly cerebrospinal fluid fistula and hypopituitarism. ${ }^{31,38}$ Probability of remission after a second 
intervention decreases by $50 \%$ if the remaining tumor invades the cavernous sinuses. ${ }^{39}$

\section{Bilateral adrenalectomy}

BA for CD treatment began in the 1950s and is currently used in refractory cases to other treatments or when RT is not used, as in the case of young patients who wish to preserve fertility. A remission rate from $80 \%-100 \% 0^{23}$ is achieved by BA in CD, but at the same time it is a risk factor for the development of Nelson syndrome (NS), which occurs in $8 \%-38 \%$ of the cases. ${ }^{40}$ The development of NS is greater if BA is performed in young patients with imaged-confirmed adenomas before surgical treatment. ${ }^{41}$ Prophylactic RT decreases the risk of developing such syndromes; nevertheless, it is usually the chosen treatment for hypophyseal tumor remnant. ${ }^{42}$ It takes from about 5-10 years to develop NS after BA. ${ }^{43,44}$ Morbidity of $9.8 \%$ and mortality of $1.1 \%$ at 30 days after adrenalectomy are reported, ${ }^{45}$ although these may be greater in the presence of comorbidities that are present per se in patients with CS, such as obesity, susceptibility to infections, and increased risk of thromboembolism, as compared with adrenalectomy performed for other reasons. ${ }^{46}$

It is possible that part of the adrenal function may be preserved following surgery, as adrenal remnants have been reported in $13 \%-27 \%$ of BAs carried out, ${ }^{47,48}$ this being a cause of disease persistence. Another noteworthy complication is deterioration of life quality due to depressive syndrome in varying degrees, fatigue being the most common symptom $(85 \%) .{ }^{47}$ Undoubtedly, a high percentage of these patients will require chronic treatment with GCs and mineralocorticoids, thus partly improving alterations in life quality.

The treatment of choice for those patients diagnosed with CS independently from ACTH is adrenalectomy, and this can be unilateral in the case of patients with adenoma or carcinoma, or bilateral in hyperplasia cases. Adenomas have a healing rate of $100 \%$ with low morbidity and mortality when under expert management. ${ }^{49,50}$ Adrenal cancer prognosis is grim if there is recurrence of liver, thoracic, or loco-regional metastases.

\section{Radiotherapy}

RT was the first-line treatment used for CD from 1940 through to 1980 , providing reduced healing rates lower than $50 \% ;^{51}$ currently, it is considered as a second-line treatment after surgery failure. If used this way, the achieved remission is from $53 \%$ to $83 \%$ with a recurrence of up to $17 \% .{ }^{52-54}$

Different techniques have been applied. The use of a gamma knife has seen remissions reported from $63 \%$ to $73 \%$; by using the lineal accelerator, data become less accurate but apparently with good results. ${ }^{55}$ If serious medical complications arise that increase anesthetic risk and therefore morbidity/mortality, then RT may be considered a first-line therapy. RT may be considered as the first-line therapy in children with remission rates similar to TSS. Nevertheless, the maximum effectiveness of RT may take as long as 1 year to be reached. Pharmacological treatment must be considered together with RT if hypercortisolism clinical manifestations are very pronounced. Growth hormone deficiency is the most common complication of RT with $50 \%$, followed by the appearance of hypogonadism to a lesser extent; damage to the optical nerve is less than $1 \%$.

The primary treatment of ectopic ACTH-dependent CS is the removal of the primary tumor, with which remission is achieved in $30 \%-47 \%$ of the cases. ${ }^{8}$ The probability of success depends upon tumor resectability and the expertise of the surgeon. However, if curative surgery fails or is not possible, then palliative treatment aims to reduce cortisol levels. BA is used in $56 \%$ of the hypercortisolemia cases that cannot be treated by other means. ${ }^{56}$ Recent advances in surgical techniques identify laparoscopic BA as an attractive alternative. $^{57}$

\section{Pharmacologic treatment for CS}

The principal treatment for CS's most frequent causes is the excision of ACTH-producing tumors or adrenal adenomas; nevertheless, pharmacologic treatment has a well-established role. Indications of medical treatment for $\mathrm{CD}$ include preoperative treatment and persistent or recurrent hypercortisolism after hypophyseal surgery and for overcoming the period until RT becomes effective. Primary medical treatment may be considered in patients with no visible hypophyseal adenoma, in patients with high surgical risk and/or significant comorbidities, and in patients with low probabilities of resolution through surgery. ${ }^{58,59}$

In the event of ectopic secretion of $\mathrm{ACTH}$, patients may require medical treatment in order to lessen the impact of comorbidities and complications associated with hypercortisolism previous to a surgical intervention; furthermore, it can be used in such cases in which there has not been a conclusion on the source of the ectopic secretion and in patients with metastatic disease and ectopic production of ACTH without possible surgery resolution. Some patients may require continued therapy in the event of acute complications (psychotic break, hypertensive crisis).

Patients with nonresectable adrenal carcinoma or metastasis of cortisol-producing adrenal carcinoma must be 
treated with agents that decrease the cortisol production rate jointly with specific tumor therapy for treating symptoms and preventing complication from hypercortisolism. ${ }^{58}$

There are pharmacologic therapies that inhibit adrenal synthesis of GCs as well as therapies intended for decreasing ACTH secretion at a pituitary level or GC receptor antagonists. We will describe several drugs with pharmacological action at the aforementioned levels.

\section{Adrenal steroid synthesis inhibitors Ketoconazole}

Since 1983, Engelhardt and Weber ${ }^{60}$ reported the usefulness of ketoconazole in a case of CS produced by an adrenocortical adenoma; afterwards, they recorded its inhibitory effect over adrenal enzymes 17, 20 desmolase (conversion of 17, 20 hydroxiprogesterone to androstendione), clarifying that the most powerful effect is here and to a lesser extent $17 \alpha$-hydroxylase (conversion of progesterone to $17 \alpha$ hydroxiprogesterone), 11 $\beta$-hydroxylase (11-desoxicortisol to cortisol), and $16 \alpha$ - and 18-hydroxilase. Both in vivo and in vitro inhibition of androgens is greater than that of cortisol (30\%-50\% vs 19\%, respectively). Ketoconazole also inhibits ACTH production and cellular growth, partly because of apoptosis induction. ${ }^{58}$ At a dose of 400-1200 mg/day it can decrease cortisol production in patients with CS from various etiologies. It can be administered two to three times a day, starting with $200 \mathrm{mg}$ twice a day and being titrated up to a maximal dose of $1200 \mathrm{mg}$ per day; therapy can be based on serum cortisol levels and UFC at 24 hours. ${ }^{58,61,62}$ Blood pressure in patients with CS may be better controlled if antihypertensive drugs are administered jointly with ketoconazole in comparison with antihypertensive drugs alone. ${ }^{63}$

An adverse effect is the increment on serum concentration of liver enzymes in 5\%-15\% of the patients; ${ }^{64}$ additionally, it can cause male hypogonadism, gynecomastia (13\%), gastrointestinal disorders $(8 \%)$, edema $(6 \%)$, and skin $\operatorname{rash}(2 \%) .{ }^{58,65}$

Reports about paraneoplasic CS indicate complete hormonal response in up to $28 \%$ of the cases, leading to symptomatic hypoadrenalism in $12 \%$ of the cases. ${ }^{61}$ No prospective studies have been conducted based on ketoconazole monotherapy. The efficacy data have been drawn from retrospective studies, most of them with a small number of patients. Castinetti et al ${ }^{66}$ reported that ketoconazole induced biochemical remission in $50 \%$ of the patients with CD. Taking into account most of the trials as a whole, ketoconazole has an efficacy of $70 \%,{ }^{66}$ and the remission rates in CD vary from $25 \%$ to $93 \% .{ }^{60,65,67,68}$
Ketoconazole has also been used in some cases of CS during pregnancy, having as side effects intrauterine growth retardation and potential antiandrogenic effects, ${ }^{69}$ embryotoxic and teratogenic potential in animals has been reported. ${ }^{70}$ A patient with $C D$ who refused surgical treatment had a normal birth through vaginal delivery at 37 weeks of gestation. ${ }^{71}$ We do not recommend the use of ketoconazole during pregnancy, as there is limited experience.

\section{Metirapone}

Metirapone it is a selective inhibitor of $11 \beta$-hydroxylase. It decreases cortisol and aldosterone synthesis, but the highest concentrations of 11-deoxycortisol preserve the mineralocorticoid functions. The maximal suppression of steroidogenesis requires the use of a $4 \mathrm{~g}$ /day dose. ${ }^{72}$ Electrolytic balance and blood pressure vary from patient to patient, depending upon the extent of aldosterone inhibition and stimulation of 11-desoxicorticosterone. ${ }^{73}$

Cortisol suppression is dose-dependent within a few hours with a dose of $4.5 \mathrm{~g} /$ day. ${ }^{74}$ The dose varies from $500 \mathrm{mg} /$ day to $6000 \mathrm{mg} /$ day; patients must be carefully monitored due to potential development of hypercorsisolism, ${ }^{58}$ being able to maintain chronic suppression with doses from $500 \mathrm{mg}$ /day to $2000 \mathrm{mg} /$ day. It may be used in patients with severe secondary hypercortisolism to ectopic cortical adrenocarcinoma or inoperable ectopic production of ACTH,${ }^{74}$ as well as adjuvant in a case of surgical failure due to $\mathrm{CD}$. In such a situation, a dose 500-750 mg three to four times daily is used. ${ }^{72}$

The compensatory increase in ACTH production due to a decrease in negative feedback in hypophyseal adenoma is a potential disadvantage in the treatment of CD. This in turn may lead to an increase in cortisol adrenal production, as well as androgens and mineralocorticoid precursors. ${ }^{58}$ Long-term administration creates hirsutism and hypertension. Other adverse effects include nausea, headache, sedation, and skin rash. ${ }^{72} \mathrm{~A}$ secondary increase of androgens is more likely in ACTH-dependent cases; meanwhile, hypertension and hypokalemia are less probable in ACTH-independent cases. $^{74}$

\section{Etomidate}

Etomidate it is a hypnotic anesthetic agent that suppresses steroidogenesis by inhibiting the cleavage of the side chain of cholesterol and 17-hydroxilase, 11- $\beta$ hydroxylase, and 17-20 lyase enzymes. It has a rapid onset of action, and it is particularly useful in patients with acute complications that compromise life, such as psychosis and severe hypertension. Most of the time it is used in patients with ectopic production 
of ACTH and excessive production of cortisol. It can be administered parentally in a dose between $0.03 \mathrm{mg} / \mathrm{kg} /$ hour and $0.3 \mathrm{mg} / \mathrm{kg} /$ hour $^{58}$ in continuous infusions, achieving a cortisol decrease in 11-24 hours. ${ }^{74}$

The use of etomidate has been reported via infusion at a dose of $3.0 \mathrm{mg} /$ hour in pediatric patients presenting psychotic episodes, in addition to simultaneous intake of hydrocortisone, maintaining a stable serum cortisol and remitting the acute condition. ${ }^{75,76}$

Adverse effects include sedation, hypotension, hypertension, and bradicardia. ${ }^{62}$ It has been associated with increased mortality in critically ill patients by causing acute adrenal insufficiency. ${ }^{7477}$ We suggest using it only in cases of complicated hypercorticism, in those who require short-term improvement, and in those who cannot use the oral route. Etomidate is recommended as a temporary treatment prior to definitive therapy.

\section{Mitotane}

Mitotane is a selective adrenolytic agent of adrenocortical cells, mainly used for adrenal carcinoma treatment. In addition to cellular growth suppression, mitotane inhibits the cleavage of the side chain of cholesterol and $11 \beta$-hydroxylase, leading to a decreased production of cortisol. ${ }^{58}$

Treatment must continue for at least 3 months; if favorable effects are observed, the treatment continues in definite form. It should not be administered concomitantly with spironolactone, as it interferes with adrenal suppression produced by mitotane. ${ }^{78}$ At low doses (2-4 g/day), it has a lower adrenolytic effect within the glomerular zone, and it is possible to have less suppressed production of aldosterone. ${ }^{74}$ Long-term remission rates with doses $\geq 4$ g (adrenolytic doses) are about $30 \%{ }^{62}$

Side effects are dose-dependent and usually intolerable with doses $>6 \mathrm{~g}$ /day. Patients must be monitored with UFC, as serum cortisol may be elevated even when free cortisol in circulation is not; the aforementioned is due to the fact that mitotane increases binding of cortisol into the corticosteroidbinding globulin. Anorexia, nausea, somnolence, lack of coordination, hepatotoxicity, and teratogenicity are some of its adverse effects. ${ }^{74}$ The adrenolytic effect involves oxidative damage by means of free-radical formation such as superoxide, which produces hydroxyl radicals and induces lipid peroxidation, leading to adrenal insufficiency and hypercholesterolemia. ${ }^{58}$

Maintenance therapy using mitotane may be a reasonable option in the case of persistent and untreatable $\mathrm{CD}^{79}$ and should be used as a last resort in case of failure or intolerance to the other drugs.

In Table 1 we briefly describe the adrenal steroidogenesis inhibitors, as well as doses and collateral effects.

\section{Therapies targeting hypophysis}

There are different kinds of drugs whose effect over hypophysis is to attempt to diminish ACTH secretion. Some of them do not have the expected success; others are still under effectiveness analysis. We describe here the different groups.

\section{Peroxisome proliferator-activated receptor gamma agonists}

Initially, these drugs produced promising results in rodents. ${ }^{80,81}$ However, this was followed by contradictory results. ${ }^{82-84}$ Later, Emery et $\mathrm{al}^{85}$ published findings about the poor expression of peroxisome proliferator-activated receptor gamma (PPAR- $\gamma$ ) receptor in hypophysis, the absence of specific abnormalities in PPAR- $\gamma$ expression in human hypophysis, and the low immunocytochemical expression in both healthy hypophysis and adenoma. All these reasons have relegated research into these CD drugs.

Table I Steroidogenesis inhibitors used in patients with Cushing syndrome $e^{65,73}$

\begin{tabular}{|c|c|c|c|c|}
\hline Drug & Initial dosage & Maximal dosage & Action mechanism & Side effects \\
\hline Ketoconazole & $200 \mathrm{mg}$ bid & $400 \mathrm{mg}$ tid & $\begin{array}{l}\text { Inhibits CYPIIBI and } \\
\text { CYPIIAI }\end{array}$ & $\begin{array}{l}\text { Abnormal liver tests } \\
\text { (I } 5 \%) \text {, gynecomastia (13\%), } \\
\text { gastrointestinal effects (8\%) }\end{array}$ \\
\hline Metyrapone & $250 \mathrm{mg}$ qid & 1500 mg qid & Inhibits CYPIIBI & $\begin{array}{l}\text { Dizziness and ataxia ( } 15 \%) \text {, } \\
\text { nausea }(5 \%) \text {, skin rash }(4 \%) \text {, } \\
\text { edema }(8 \%) \text {, and } \\
\text { hirsutism }(70 \%)\end{array}$ \\
\hline Mitotane & 500 mg qid & $3000 \mathrm{mg}$ tid & $\begin{array}{l}\text { Adrenolytic, inhibits CYPIIBI and } \\
\text { CYPIIAI }\end{array}$ & $\begin{array}{l}\text { Abnormal liver tests, } \\
\text { teratogen }\end{array}$ \\
\hline Etomidate & $\begin{array}{l}\text { Bolus } 0.03 \mathrm{mg} / \mathrm{kg} \text { intravenous } \\
\text { followed by infusion } 0.1 \mathrm{mg} / \mathrm{kg} / \mathrm{hour}\end{array}$ & $0.3 \mathrm{mg} / \mathrm{kg} / \mathrm{hour}$ & $\begin{array}{l}\text { Inhibits CYPI7, CYPI7-20 and } \\
\text { CYPIIBI }\end{array}$ & $\begin{array}{l}\text { Hypotension, } \\
\text { sedation }\end{array}$ \\
\hline
\end{tabular}

Abbreviations: bid, twice daily; qid, four times daily; tid, three times daily. 


\section{Valproic acid}

Valproic acid is a drug that can potentially suppress ACTHreleasing hormone. Different assays have not shown efficacy in $\mathrm{CD}^{74}$ It has been used as a therapeutic adjuvant in NS cases. ${ }^{86}$ So far, there are not many data that can prove its usefulness. ${ }^{87}$ Other drugs like cyproheptadine have had the same results. $74,87,88$

\section{Somatostatin and pasireotide analogs}

Somatostatin is a cyclopeptide that is present in two active forms of 14 and 28 amino acids widely distributed in the brain and peripheral tissues. It regulates the release of some hormones and inhibits endocrine and exocrine secretions. Biologic actions of somatostatin are mediated by 5 G-proteincoupled receptors, namely somatostatin receptor type 1 to $5\left(\right.$ sst $\left._{1-5}\right) .{ }^{89}$

$\mathrm{sst}_{1}, \mathrm{sst}_{2}, \mathrm{sst}_{4}$, and $\mathrm{sst}_{5}$ inhibit cell proliferation. $\mathrm{sst}_{3}$ is cytotoxic and produces cell death or apoptosis. ${ }^{87}$ The natural somatostatin is fixed with great affinity to all of the five receptors. However, utility of somatostatin is limited by its accelerated catabolism at serum level. Different metabolically stable analogs of somatostatin have been synthesized, like octreotide and lanreotide, which bind only to $\mathrm{sst}_{2}$, having a slight affinity for sst $_{3}$ and sst $_{5}$ and a very low or absent affinity for sst ${ }_{1}$ and sst $_{4}$. Somatostatin and octreotide have not been demonstrated to significantly inhibit ACTH secretion in patients with $\mathrm{CD} .{ }^{90,91}$

Pasireotide is a recent analog of somatostatin with multireceptor activity. It is a cyclohexapeptide that bonds with great affinity to all sst receptors, except $\mathrm{sst}_{4}{ }^{90,92}$ In contrast with octreotide, pasireotide shows high subnanomolar affinity for sst $_{5}$ and an improved metabolic stability. Lesche et al ${ }^{90}$ showed that pasireotide is more potent than octreotide for inducing internalization and signaling of sst ${ }_{3}$ and $\mathrm{sst}_{5}$ receptors, which are predominant in hypophyseal adenomas that produce $\mathrm{ACTH}$, and at the same time their expression diminishes in adenomas with aggressive behavior. ${ }^{93}$ The functional activity of pasireotide over $\mathrm{sst}_{1}, \mathrm{sst}_{3}$, and $\mathrm{sst}_{5}$ is $>30$, eleven, and 158 times higher, respectively, and is seven times lower over sst ${ }_{2}{ }^{92}$ Pasireotide has shown inhibition of basal and stimulated release of ACTH from ACTH-producer hypophyseal adenomas. ${ }^{87}$

In a phase II trial ${ }^{94}$ that included patients with recent $\mathrm{CD}$ diagnosis or with postsurgical relapse (excluding those receiving RT), a $600 \mu \mathrm{g}$ dose every 12 hours over 15 days was used, recording a UFC decrease in $76 \%$ of the patients. From these, $17 \%$ reached normal UFC concentrations; in addition, direct effects upon ACTH release were observed. Pasireotide safety has been assessed in healthy volunteers and in cases of acromegaly, $\mathrm{CD}$, and carcinoid syndrome carriers; the most common side effects are the gastrointestinal ones and transient increases in fasting glucose ${ }^{89} \mathrm{In}$ order to determine the role of pasireotide in patients with $\mathrm{CD}$ de novo, persistent or recurrent, the phase III, multicenter, randomized, doubleblind PASPORT (Pasireotide Clinical Trial Portfolio) trial is being conducted, and we are still waiting for official results..$^{95}$ Because somatostatin receptors have been found in normal adrenal cortex and adrenocortical tumors, pasireotide may have a potential effect at this level. ${ }^{89}$ An 80 -day clinical trial has recently been performed in 17 patients with $\mathrm{CD}$ in order to examine the efficacy of the medical therapy based on treatment with pasireotide and sequentially extended with cabergoline and ketoconazole. Treatment began with $100 \mu \mathrm{g}$ subcutaneous pasireotide three times a day. If the UFC had not normalized at day 15 , the pasireotide dose was increased up to $250 \mu \mathrm{g}$ three times a day. At day 28 and upon persistent elevation of UFC level, cabergoline was administered. If UFC was not normalized by day 60 , a $200 \mathrm{mg}$ dose of ketoconazole three times a day was added. Pasireotide induced normalization of UFC in four of 17 patients at day 60 , while eight of 17 patients still had an elevated UFC, despite combination therapy; added ketoconazole induced complete response in $88 \%$ of patients, thus improving blood pressure and weight. ${ }^{96}$

Somatostatin and analogs are therefore capable of suppressing secretion of ACTH originating from ectopic neuroendocrine tumor; positive octreoscan gammagraphy of tumors ( ${ }^{111}$ In-pentreotide) would be an indicator of somatostatin receptors, making them more likely to respond to this therapy with suppression of ACTH and cortisol. Nevertheless, expression or recording of such receptors is highly variable. ${ }^{74,97}$ According to previous reports and probably due to the presence of high levels of cortisol that induce downregulation of $\mathrm{sst}_{2}$, octreotide (specifically) has proven to have limited usefulness. ${ }^{98} \mathrm{~A}$ valuable tool in the future with the potential for optimizing drug therapy would be a targeted search of somatostatin tumor receptors using rabbit monoclonal antibodies UMB-4 and UMB-1 during routine histopathological studies, and thus the best drug selected according to the prevailing receptor. ${ }^{99}$

\section{Dopaminergic agonists and cabergoline}

Dopamine is the predominant catecholaminergic neurotransmitter in the central nervous system, acting by means of receptors $\left(D_{1-5}\right)$. The $D_{2}$ receptor is expressed in the anterior and intermediate lobe of the hypophysis, showing heterogeneous and variable expression in $89 \%$ of 
all hypophyseal tumor types. The expression of receptor $\mathrm{D}_{2}$ has been detected in $23 \%-80 \%$ of the ACTH-secreting hypophyseal adenomas, and it has been correlated with an inhibitory effect of dopaminergic agonists in the secretion of ACTH in vitro. ${ }^{87,93}$

Bromocriptine is a $\mathrm{D}_{2}$ agonist and $\mathrm{D}_{1}$ antagonist; in cell cultures of human hypophyseal tumors it suppresses the secretion of ACTH and induces apoptosis in AtT-20 cells. ${ }^{87}$ Moderate results have been reported with doses from $17.5 \mathrm{mg} /$ day to $40 \mathrm{mg} /$ day. ${ }^{100}$ In different studies, the effectiveness of bromocriptine varies between $0 \%$ and $50 \%$ and may be $\leq 10 \%,{ }^{87,100}$ with few results on a long-term basis. ${ }^{1}$

Cabergoline is a dopaminergic agonist with greater selectivity and affinity for the $\mathrm{D}_{2}$ receptor than bromocriptine. ${ }^{100}$ Godbout et $\mathrm{al}^{101}$ performed a retrospective analysis of cabergoline monotherapy in 30 patients with $\mathrm{CD}$, beginning with a dose of $0.5-1.0 \mathrm{mg} /$ week and progressive titrations up to a maximum dose of $6 \mathrm{mg} /$ week; taking UFC as a parameter, $36.6 \%$ of the patients showed a complete response within 3-6 months, $13.3 \%$ showed a partial response, and $30 \%$ maintained the response on a long-term basis (mean of 37 months) with a dose of $2.1 \mathrm{mg} /$ week. Pivonello et al ${ }^{102}$ performed a prospective trial in 20 patients with surgical treatment and without disease remission with initial doses of $1 \mathrm{mg} /$ week and monthly titrations until obtaining a response or until achieving a dose of $7 \mathrm{mg} /$ week (mean $3.5 \mathrm{mg} /$ week), reporting 3 months later with response to cabergoline in 15 patients $(75 \%)$. In these patients it was maintained in ten. In only eight (40\%) was sustained control at 24 months achieved; additionally, there was a tumor decrease in $20 \%$ of the patients and improvement of hypertension and glucose intolerance in most of them, independently from changes in UFC. In contrast, Lila et al ${ }^{103}$ conducted another prospective trial, which included 20 patients without surgery remission with or without RT adjuvant, with an initial dose of $1 \mathrm{mg} /$ week and a maximal dose of $5 \mathrm{mg} /$ week (mean $3.6 \mathrm{mg} /$ week) and monitoring throughout the year, wherein serum markers were assessed and pharmacologic response reported of $28 \%, 25 \%$, and $17 \%$. Limitations of the study were the short follow-up and lack of UFC.

Vilar et al $^{104}$ studied combination therapy by assessing the effectiveness of cabergoline ( $3 \mathrm{mg} /$ week) alone or in combination with ketoconazole ( $<400 \mathrm{mg} /$ day) in twelve patients with $C D$ and unsatisfactorily treated with TSS. After a 6-month treatment with monodoses of cabergoline 2-3 mg/week, UFC was normalized in $25 \%$ of the patients, with UFC reductions from $15 \%$ to $48.8 \%$; administration of ketoconazole to the remaining nine showed UFC normalization in six of them $(66.7 \%)$, with doses from $200 \mathrm{mg} /$ day to $400 \mathrm{mg}$ /day.

It should be taken into account that there is no homology in the different biochemical criteria regarding complete or partial response and reduction percentage in several studies: some use UFC, others use a $1 \mathrm{mg}$ dexamethasone test, and others refer to serum cortisol; likewise, maximum doses and follow-up times differ, therefore results are not totally equivalent. We need more prospective studies with better homogeneity regarding criteria, dose, and time in order to set up a clear position regarding the utility of dopaminergic agonists; for the time being, we could consider cabergoline as the best option due to its selectivity on $\mathrm{D}_{2}$, greater tolerability, and best evidence in the long-term follow-up. Variability on results also corresponds to the aforementioned variability in expression of dopamine receptors in hypophyseal adenomas.

Mifepristone is a synthetic steroid (derivative of the synthetic progestin norethindrone) acting as a potent antagonist of progesterone and cortisol. ${ }^{105,106}$ When administered in high doses, it is a potent antagonist of GC. ${ }^{107}$ It blocks the actions of hypercorticism on target organs by blocking the GC receptor type II. ${ }^{62}$ It can antagonize the acute effects of cortisol over the protein and carbohydrate metabolism and inhibit the cortisol-induced peripheral vasoconstriction. Its applications under hypercortisolism include $\mathrm{CD}$, adrenal adenoma, adrenocortical carcinoma, and ectopic production of ACTH. ${ }^{107}$ Mifepristone and its metabolites have a greater affinity for the GC receptor (mifepristone, 100\%; metabolites, $45 \%-61 \%)$ than dexamethasone (23\%) and cortisol (9\%). ${ }^{106}$ A problem with the drug is that ACTH and serum cortisol do not provide any relevant information regarding efficacy; it should be judged only upon a clinical basis. ${ }^{62}$ In fact, the increase of ACTH and cortisol by feedback is a potent adverse effect in patients with CD. Because no mineralocorticoid receptor is blocked, an increase in cortisol can lead to hypokalemia, which may require a mineralocorticoid antagonist such as spironolactone or eplerrenone. Hypercortisolism symptoms, namely anorexia, nausea, arthralgia, and headache, may occur and require dose adjustments. ${ }^{74}$

Johanssen and Allolio ${ }^{108}$ conducted a retrospective analysis for hypercortisolism treatment with mifepristone in a total of 18 patients. Daily doses varied from $5 \mathrm{mg} / \mathrm{kg}$ to $30 \mathrm{mg} / \mathrm{kg}$; the results suggest a significant improvement in patients in whom surgery and adrenal steroidogenesis inhibitors failed to control the overproduction of cortisol. A very positive feature is its rapid onset of action, making it particularly useful in acute cortisol-induced psychosis. Adrenal failure must be taken into account. There have been 
two cases reported that point to the use of mifepristone allowing the "positivization" of two bronchial carcinoid tumors that initially did not capture ${ }^{111}$ In-pentetreotide (octreoscan). The findings support the theory of inhibition in expression of $\mathrm{sst}_{2}$ in neuroendocrine tumor cells by hypercortisolism. This opens a new window in the potential indications of mifepristone, with "therapeutic-diagnostic" utility and even increasing diagnostic sensitivity previously reported for octreoscan $\left(\approx 50 \%\right.$ in most of the series). ${ }^{97}$

In February 2012, the Food and Drug Administration passed mifepristone use for treating chronic hyperglycemia in patients with uncontrolled CD. We suggest that it can be employed in cases of partial efficacy, intolerance, or lack of access to other drugs, either as a replacement of those or as adjuvant therapy, in a psychotic crisis case, or in those who require a rapid response because of the severity of the clinical symptoms. It must not be used during pregnancy.

As for future potential treatments, we can discuss dopastatin (BIM-23A760), which is a chimeric molecule with which we are seeking to exploit the theoretical potential of somatostatin and dopamine receptor interactions. This compound presents high activity on $\mathrm{D}_{2}$ and $\mathrm{sst}_{2}$ receptors and is moderate on $\mathrm{sst}_{5}$. Its role in nonfunctional hypophyseal adenomas is to exert a cytostatic and cytotoxic effect, mainly mediated by $\mathrm{D}_{2}{ }^{109}$ Regarding its role in ACTH-producing adenomas, in vitro preliminary results are encouraging because they show inhibition of dose-dependent cell replication in $60 \%$ of cases; however, there are still few data. ${ }^{110}$

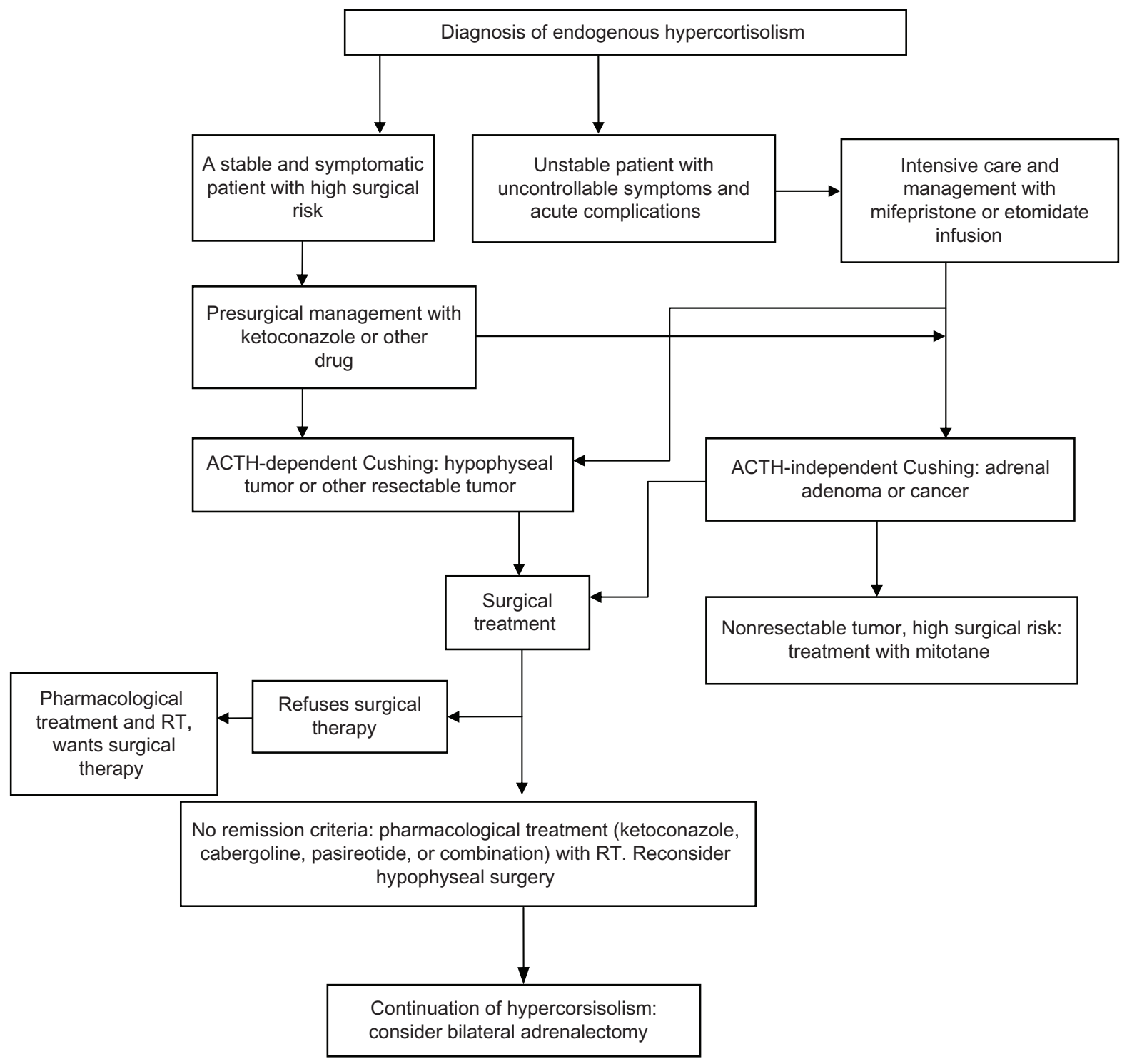

Figure I Treatment of Cushing syndrome.

Abbreviations: ACTH, corticotrophin; RT, radiotherapy. 


\section{Conclusion}

We conclude by remarking that although diagnostic and therapeutic techniques have been substantially improved, CS is still a challenge regarding its treatment, particularly if the disease persists after first-line therapy. Finally, we suggest a simple therapeutic algorithm (Figure 1) for CS treatment.

\section{Disclosure}

The authors have no conflict of interest relevant to this manuscript to declare.

\section{References}

1. Pivonello R, De Martino MC, De Leo M, Lombardi G, Colao A. Cushing's syndrome. Endocrinol Metab Clin N Am. 2008;37(1):135-149.

2. Espinosa de los Monteros-Sánchez AL, Valdivia-López J, MendozaZubieta V, Mercado-Atri M, Gómez-Pérez F, Romero-Zazueta A, et al. Consenso en el diagnóstico y tratamiento del síndrome de Cushing. Rev Endocrinol Nutr. 2007;15(4):S3-S12.

3. Lindholm J, Jull SJ, Jorgensen JO, Astrup J, Bjerre P, Feldt-Rasmussen U, et al. Incidence and late prognosis of Cushing's syndrome: a population-based study. Clin Endocrinol Metab. 2001;86: 117-123.

4. Curtis JR, Westfall AO, Allison J, Bijlsma JM, Freeman A, George V, et al. Population-based assessment of adverse events associated with long-term glucocorticoid use. Arthritis Rheum. 2006;55(3):420-426.

5. McDonough AK, Curtis JR, Saag KG. The epidemiology of glucocorticoid-associated adverse events. Curr Opin Rheumatol. 2008;20(2):131-137.

6. Newell-Price J, Bertagna X, Grossman AB, Nieman LK. Cushing's syndrome. Lancet. 2006;367(9522):1605-1617.

7. Catargi B, Rigalleau V, Poussin A, et al. Occult Cushing's syndrome in type-2 diabetes. J Clin Endocrinol Metab. 2003;88(12):5808-5813.

8. Isidori AM, Kaltsas GA, Pozza C, et al. The ectopic adrenocorticotropin syndrome: clinical features, diagnosis, management and long-term follow-up. J Clin Endocrinol Metab. 2006;91(2):371-377.

9. Boscaro M, Barzon L, Fallo F, Sonino N. Cushing's syndrome. Lancet. 2001;357(9258):783-791.

10. Pivonello R, Faggiano A, Lombardi G, Colao A. The metabolic syndrome and cardiovascular risk in Cushing's syndrome. Endocrinol Metab Clin North Am. 2005;34(2):327-339.

11. Nieman LK, Biller BM, Findling JW, et al. The diagnosis of Cushing's syndrome: an Endocrine Society clinical practice guideline. J Clin Endocrinol Metab. 2008;93(5):1526-1540.

12. González Albarrán O, García-Robles R. Síndrome de Cushing. Medicine. 2000;8:1102-1111.

13. Axelrod L. Glucocorticoid therapy. Medicine. 1976;56:39-65.

14. Livanou T, Ferriman D, James VH. Recovery of hypothalamo-pituitaryadrenal function after corticosteroid therapy. Lancet. 1967;2(7521): 856-859.

15. Robinson BH, Mattingly D, Cope CL. Adrenal function after prolonged corticosteroid therapy. Br Med J. 1962;1(5292):1579-1584.

16. LaRochelle GE Jr, LaRochelle AG, Ratner RE, Borenstein DG. Recovery of the hypothalamic-pituitary-adrenal (HPA) axis in patients with rheumatic diseases receiving low-dose prednisone. Am J Med. 1993;95(3):258-264.

17. Pérez EG, Hernández EA, Zuñiga AE, et al. Comparison of the severity index in Cushing's syndrome between patients with endogenous and iatrogenic disease. Endocrinol Nutr. 2010;57(9):426-433.

18. Richter B, Neises G, Clar C. Glucocorticoid withdrawal schemes in chronic medical disorders. A systematic review. Endocrinol Metab Clin North Am. 2002;31(3):751-778.
19. Hopkins RL, Leinung MC. Exogenous Cushing's syndrome and glucocorticoid withdrawal. Endocrinol Metab Clin North Am. 2005; 34(2):371-384.

20. Axelrod L. Corticosteroid therapy. Principles and Practice of Endocrinology and Metabolism. Becker KL, ed. Philadelphia, PA: Lippincott Williams and Wilkins; 2001:751-764.

21. Mantero F, Scaroni CM, Albiger NM. Cyclic Cushing's syndrome: an overview. Pituitary. 2004;7(4):203-207.

22. Orth DN. Cushing's syndrome. N Engl J Med. 1995;332(12):791-803.

23. Kelly DF. Transsphenoidal surgery for Cushing's disease: a review of success rates, remission predictors, management of failed surgery, and Nelson's syndrome. Neurosurg Focus. 2007;23(3):E5.

24. Bigos ST, Robert F, Pelletier G, Hardy J. Cure of Cushing's disease by transsphenoidal removal of a microadenoma from a pituitary gland despite a radiographically normal sella turcica. J Clin Endocrinol Metab. 1977;45(6):1251-1260.

25. Hardy J. The transsphenoidal surgical approach to the pituitary. Hosp Pract. 1979;14(6):81-89.

26. Salassa RM, Laws ER Jr, Carpenter PC, Northcutt RC. Transsphenoidal removal of pituitary microadenoma in Cushing's disease. Mayo Clin Proc. 1978;53(1):24-28.

27. Tyrrell JB, Brooks RM, Fitzgerald PA, Cofoid PB, Forsham PH, Wilson CB. Cushing's disease. Selective trans-sphenoidal resection of pituitary microadenomas. N Engl J Med. 1978;298(14):753-758.

28. Fomekong E, Maiter D, Grandin C, Raftopoulos C. Outcome of transsphenoidal surgery for Cushing's disease: a high remission rate in ACTH-secreting macroadenomas. Clin Neurol Neurosurg. 2009; 111(5):442-449.

29. Shimon I, Ram Z, Cohen ZR, Hadani M. Transsphenoidal surgery for Cushing's disease: endocrinological follow-up monitoring of 82 patients. Neurosurgery. 2002;51(1):57-62.

30. Rees DA, Hanna FW, Davies JS, Mills RG, Vafidis J, Scanlon MF. Long-term follow-up results of transsphenoidal surgery for Cushing's disease in a single centre using strict criteria for remission. Clin Endocrinol (Oxf). 2002;56(4):541-551.

31. Chee GH, Mathias DB, James RA, Kendall-Taylor P. Transsphenoidal pituitary surgery in Cushing's disease: can we predict outcome? Clin Endocrinol (Oxf). 2001;54(5):617-626.

32. Netea-Maier RT, van Lindert EJ, den Heijer M, et al. Transsphenoidal pituitary surgery via the endoscopic technique: results in 35 consecutive patients with Cushing's disease. Eur J Endocrinol. 2006;154(5): 675-684.

33. Lindsay JR, Oldfield EH, Stratakis CA, Nieman LK. The postoperative basal cortisol and $\mathrm{CRH}$ tests for prediction of long-term remission from Cushing's disease after transsphenoidal surgery. J Clin Endocrinol Metab. 2011;96(7):2057-2064.

34. Esposito F, Dusick J, Cohan P, et al. Clinical review: early morning cortisol levels as a predictor of remission after transsphenoidal surgery for Cushing's disease. J Clin Endocrinol Metab. 2006;91(1):7-13.

35. Chen JC, Amar AP, Choi S, Singer P, Couldwell WT, Weiss MH. Transsphenoidal microsurgical treatment of Cushing disease: postoperative assessment of surgical efficacy by application of an overnight low-dose dexamethasone suppression test. J Neurosurg. 2003;98(5):967-973.

36. Patil CG, Lad SP, Harsh GR, Laws ER Jr, Boakye M. National trends, complications, and outcomes following transsphenoidal surgery for Cushing's disease from 1993 to 2002. Neurosurg Focus. 2007;23(3):E7.

37. Barker FG 2nd, Klibanski A, Swearingen B. Transsphenoidal surgery for pituitary tumors in the United States, 1996-2000: mortality, morbidity, and the effects of hospital and surgeon volume. J Clin Endocrinol Metab. 2003;88(10):4709-4719.

38. Locatelli M, Vance ML, Laws ER. Clinical review: the strategy of immediate reoperation for transsphenoidal surgery for Cushing's disease. J Clin Endocrinol Metab. 2005;90(9):5478-5482.

39. Cannavò S, Almoto B, Dall'Asta C, et al. Long-term results of treatment in patients with ACTH-secreting pituitary macroadenomas. Eur $J$ Endocrinol. 2003;149(3):195-200. 
40. Kemink L, Pieters G, Hermus A, Smals A, Kloppenborg P. Patient's age is a simple predictive factor for the development of Nelson's syndrome after total adrenalectomy for Cushing's disease. J Clin Endocrinol Metab. 1994;79(3):887-889.

41. Sonino N, Zielezny M, Fava GA, Fallo F, Boscaro M. Risk factors and long-term outcome in pituitary-dependent Cushing's disease. J Clin Endocrinol Metab. 1996;81(7):2647-2652.

42. Jenkins PJ, Trainer PJ, Plowman PN, et al. The long-term outcome after adrenalectomy and prophylactic pituitary radiotherapy in adrenocorticotropin-dependent Cushing's syndrome. J Clin Endocrinol Metab. 1995;80(1):165-171.

43. Invitti C, Pecori Giraldi F, de Martin M, Cavagnini F. Diagnosis and management of Cushing's syndrome: results of an Italian multicentre study. Study Group of the Italian Society of Endocrinology on the Pathophysiology of the Hypothalamic-Pituitary-Adrenal Axis. J Clin Endocrinol Metab. 1999;84(2):440-448.

44. Kasperlik-Załuska AA, Nielubowicz J, Wisławski J, et al. Nelson's syndrome: incidence and prognosis. Clin Endocrinol (Oxf). 1983;19(6): 693-698.

45. Turrentine FE, Henderson WG, Khuri SF, et al. Adrenalectomy in Veterans Affairs and selected university medical centers: results of the patient safety in surgery study. J Am Coll Surg. 2007;204(6): 1273-1283.

46. Poulin EC, Schlachta CM, Burpee SE, Pace KT, Mamazza J. Laparoscopic adrenalectomy: pathologic features determine outcome. Can J Surg. 2003;46(5):340-344.

47. Smith PW, Turza KC, Carter CO, Vance ML, Laws ER, Hanks JB. Bilateral adrenalectomy for refractory Cushing's disease: a safe and definitive therapy. J Am Coll Surg. 2009;208(6):1059-1064

48. Nagesser SK, van Seters AP, Kievit J, Hermans J, Krans HM, van de Velde CJ. Long-term results of total adrenalectomy for Cushing's disease. World J Surg. 2000;24(1):108-113.

49. Välimäki M, Pelkonen R, Porkka L, Sivula A, Kahri A. Long-term results of adrenal surgery in patients with Cushing's syndrome due to adrenocortical adenoma. Clin Endocrinol (Oxf). 1984;20(2): 229-236.

50. Sarkar R, Thompson NW, McLeod MK. The role of adrenalectomy in Cushing's syndrome. Surgery. 1990;108(6):1079-1084.

51. Howlett TA, Plowman PN, Wass JA, Rees LH, Jones AE, Besser GM. Megavoltage pituitary irradiation in the management of Cushing's disease and Nelson's syndrome: long-term follow-up. Clin Endocrinol (Oxf). 1989;31(3):309-323.

52. Estrada J, Boronat M, Mielgo M, et al. The long-term outcome of pituitary irradiation after unsuccessful transsphenoidal surgery in Cushing's disease. $N$ Engl J Med. 1997;336(3):172-177.

53. Imaki T, Tsushima T, Hizuka N, et al. Postoperative plasma cortisol levels predict long-term outcome in patients with Cushing's disease and determine which patients should be treated with pituitary irradiation after surgery. Endocr J. 2001;48(1):53-62.

54. Vicente A, Estrada J, de la Cuerda C, et al. Results of external pituitary irradiation after unsuccessful transsphenoidal surgery in Cushing's disease. Acta Endocrinol (Copenh). 1991;125(5):470-474.

55. Swords FM, Allan CA, Plowman PN, et al. Stereotactic radiosurgery XVI: a treatment for previously irradiated pituitary adenomas. J Clin Endocrinol Metab. 2003;88(11):5334-5340.

56. Alexandraki KI, Grossman AB. The ectopic ACTH syndrome. Rev Endocr Metab Disord. 2010;11(2):117-126.

57. Zografos GN, Markou A, Ageli C, et al. Laparoscopic surgery for adrenal tumors. A retrospective analysis. Hormones (Athens). 2006;5(1):52-56.

58. Feelders RA, Hofland LJ, de Herder WW. Medical treatment of Cushing's syndrome: adrenal-blocking drugs and ketaconazole. Neuroendocrinology. 2010;92 Suppl 1:S111-S115.

59. Arnaldi G, Boscaro M. Pasireotide for the treatment of Cushing's disease. Expert Opin Investig Drugs. 2010;19(7):889-898.
60. Engelhardt D, Weber MM. Therapy of Cushing's syndrome with steroid biosynthesis inhibitors. J Steroid Biochem Mol Biol. 1994;49(4-6): 261-267.

61. Winquist EW, Laskey J, Crump M, Khamsi F, Shepherd FA. Ketoconazole in the management of paraneoplastic Cushing's syndrome secondary to ectopic adrenocorticotropin production. J Clin Oncol. 1995;13(1):157-164.

62. Patil CG, Hayden M, Katznelson L, Chang SD. Non-surgical management of hormone-secreting pituitary tumors. J Clin Neurosci. 2009;16(8):985-993.

63. Sharma ST, Nieman LK. Cushing's syndrome: all variants, detection, and treatment. Endocrinol Metab Clin North Am. 2011;40(2):379-391.

64. Nieman LK, Ilias I. Evaluation and treatment of Cushing's syndrome. Am J Med. 2005;118(12):1340-1346.

65. Biller BM, Colao A, Petersenn S, Bonert VS, Boscaro M. Prolactinomas, Cushing's disease and acromegaly: debating the role of medical therapy for secretory pituitary adenomas. BMC Endocr Disord. 2010;10:10.

66. Castinetti F, Morange I, Jaquet P, Conte-Devolx B, Brue T. Ketoconazole revisited: a preoperative or postoperative treatment in Cushing's disease. Eur J Endocrinol. 2008;158(1):91-99.

67. Bademci G. Pitfalls in the management of Cushing's disease. J Clin Neurosci. 2007;14(5):401-409.

68. Liubinas SV, Porto LD, Kaye AH. Management of recurrent Cushing's disease. J Clin Neurosci. 2011;18(1):7-12.

69. Lekarev O, New MI. Adrenal disease in pregnancy. Best Pract Res Clin Endocrinol Metab. 2011;25(6):959-973.

70. Berwaerts J, Verhelst J, Mahler C, Abs R. Cushing's syndrome in pregnancy treated by ketaconazole: case report and review of the literature. Gynecol Endocrinol. 1999;13(3):175-182.

71. Yawar A, Zuberi LM, Haque N. Cushing's disease and pregnancy: case report and literature review. Endocr Pract. 2007;13(3):296-299.

72. Schimmer BP, Parker KL. Corticotropina, esteroides de la corteza suprarrenal y sus análogos sintéticos, inhibidores de la síntesis y efectos de las hormonas suprarrenales. Goodman and Gilman, Las bases farmacológicas de la terapéutica. Brunton LL, Lazo JS, Parker KL, editors. México: McGraw-Hill; 2007:1587-1612.

73. Biller BM, Grossman AB, Stewart PM, et al. Treatment of adrenocorticotropin-dependent Cushing's syndrome: a consensus statement. J Clin Endocrinol Metab. 2008;93(7):2454-2462.

74. Schteingart DE. Drugs in the medical treatment of Cushing's syndrome. Expert Opin Emerg Drugs. 2009;14(4):661-671.

75. Greening JE, Brain CE, Perry LA, et al. Efficient short-term control of hypercortisolaemia by low-dose etomidate in severe paediatric Cushing's disease. Horm Res. 2005;64(3):140-143.

76. Chan LF, Vaidya M, Westphal B, et al. Use of intravenous etomidate to control acute psychosis induced by the hypercortisolaemia in severe paediatric Cushing's disease. Horm Res Paediatr. 2011;75(6):441-446.

77. Albert SG, Ariyan S, Rather A. The effect of etomidate on adrenal function in critical illness: a systematic review. Intensive Care Med. 2011;37(6):901-910.

78. Chabner BA, Amrein PC, Druker BJ, et al. Fármacos antineoplásicos. Goodman and Gilman, Las bases farmacológicas de la terapéutica. Brunton LL, Lazo JS, Parker KL, editors. México: McGraw-Hill; 2007: 1315-1403.

79. Kawai S, Ichikawa Y, Kaburaki J, Yoshida T. 18 years mitotane therapy for intractable Cushing's disease. Lancet. 1999;354(9182):951.

80. Heaney AP, Fernando M, Yong WH, Melmed S. Functional PPARgamma receptor is a novel therapeutic target for ACTH-secreting pituitary adenomas. Nat Med. 2002;8(11):1281-1287.

81. Heaney AP, Fernando M, Melmed S. PPAR-gamma receptor ligands: novel therapy for pituitary adenomas. J Clin Invest. 2003;111(9): 1381-1388.

82. Ambrosi B, Dall'Asta C, Cannavo S, et al. Effects of chronic administration of PPAR-gamma ligand rosiglitazone in Cushing's disease. Eur J Endocrinol. 2004;151(2):173-178. 
83. Pecori Giraldi F, Scaroni C, Arvat E, et al. Effect of protracted treatment with rosiglitazone, a PPARgamma agonist, in patients with Cushing's disease. Clin Endocrinol (Oxf). 2006;64(2):219-224.

84. Suri D, Weiss RE. Effect of pioglitazone on adrenocorticotropic hormone and cortisol secretion in Cushing's disease. J Clin Endocrinol Metab. 2005;90(3):1340-1346.

85. Emery MN, Leontiou C, Bonner SE, et al. PPAR-gamma expression in pituitary tumours and the functional activity of the glitazones: evidence that any anti-proliferative effect of the glitazones is independent of the PPAR-gamma receptor. Clin Endocrinol (Oxf). 2006;65(3):389-395.

86. Gil-Cárdenas A, Herrera MF, Díaz-Polanco A, Rios JM, Pantoja JP. Nelson's syndrome after bilateral adrenalectomy for Cushing's disease. Surgery. 2007;141(2):147-152.

87. Alexandraki KI, Grossman AB. Pituitary-targeted medical therapy of Cushing's disease. Expert Opin Investig Drugs. 2008;17(5):669-677.

88. Casulari LA, Naves LA, Mello PA, Pereira Neto A, Papadia C. Nelson's syndrome: complete remission with cabergoline but not with bromocriptine or cyproheptadine treatment. Horm Res. 2004;62(6): 300-305.

89. Arnaldi G, Boscaro M. Pasireotide for the treatment of Cushing's disease. Expert Opin Investig Drugs. 2010;19(7):889-898.

90. Lesche S, Lehmann D, Nagel F, Schmid HA, Schulz S. Differential effects of octreotide and pasireotide on somatostatin receptor internalization and trafficking in vitro. J Clin Endocrinol Metab. 2009; 94(2):654-661.

91. Batista DL, Zhang X, Gejman R, et al. The effects of SOM230 on cell proliferation and adrenocorticotropin secretion in human corticotroph pituitary adenomas. J Clin Endocrinol Metab. 2006;91(11): 4482-4488.

92. de Bruin C, Pereira AM, Feelders RA, et al. Coexpression of dopamine and somatostatin receptor subtypes in corticotroph adenomas. J Clin Endocrinol Metab. 2009;94(4):1118-1124.

93. Boscaro M, Ludlam WH, Atkinson B, et al. Treatment of pituitarydependent Cushing's disease with multireceptor ligand somatostatin analog pasireotide (SOM230): a multicenter, phase II trial. J Clin Endocrinol Metab. 2009;94(1):115-122.

94. Liu X, Zhu F, Ma X, et al. The Therapeutic Target Database: an internet resource for the primary targets of approved, clinical trial and experimental drugs. Expert Opin Ther Targets. 2011;15(8):903-912.

95. Feelders RA, de Bruin C, Pereira AM, et al. Pasireotide alone or with cabergoline and ketoconazole in Cushing's disease. $N$ Engl J Med. 2010;362(19):1846-1848.

96. de Bruin C, Hofland LJ, Nieman LK, et al. Mifepristone effects on tumor somatostatin receptor expression in two patients with Cushing's syndrome due to ectopic adrenocorticotropin secretion. J Clin Endocrinol Metab. 2012;97(2):455-462.
97. van der Hoek J, Waaijers M, van Koetsveld PM, et al. Distinct functional properties of native somatostatin receptor subtype 5 compared with subtype 2 in the regulation of ACTH release by corticotroph tumor cells. Am J Physiol Endocrinol Metab. 2005;289(2):E278-E287.

98. Lupp A, Hunder A, Petrich A, Nagel F, Doll C, Schultz S. Reassessment of sst(5) somatostatin receptor expression in normal and neoplastic human tissues using de novel rabbit monoclonal antibody UMB-4. Neuroendocrinology. 2011;94(3):255-264.

99. Colao A, Lombardi G, Annunziato L. Cabergoline. Expert Opin Pharmacother. 2000;1(3):555-574.

100. Páez-Pereda M, Arzt E, Stalla GK. Cushing's syndrome: drug targets and therapeutic options. Expert Opin Ther Pat. 2002;12(10):1537-1546.

101. Godbout A, Manavela M, Danilowicz K, Beauregard H, Bruno OD, Lacroix A. Cabergoline monotherapy in the long-term treatment of Cushing's disease. Eur J Endocrinol. 2010;163(5):709-716.

102. Pivonello R, De Martino MC, Cappabianca P, et al. The medical treatment of Cushing's disease: effectiveness of chronic treatment with the dopamine agonist cabergoline in patients unsuccesfully treated by surgery. J Clin Endocrinol Metab. 2009;94(1):223-230.

103. Lila AR, Gopal RA, Acharya SV, et al. Efficacy of cabergoline in uncured (persistent or recurrent) Cushing disease after pituitary surgical treatment with or without radiotherapy. Endocr Pract. 2010; 16(6):968-976.

104. Vilar L, Naves LA, Azevedo MF, et al. Effectiveness of cabergoline in monotherapy and combined with ketoconazole in the management of Cushing's disease. Pituitary. 2010;13(2):123-129.

105. Im A, Appleman LJ. Mifepristone: pharmacology and clinical impact in reproductive medicine, endocrinology and oncology. Expert Opin Pharmacother. 2010;11(3):481-488.

106. Spitz IM. Progesterone antagonists and progesterone receptor modulators: an overview. Steroids. 2003;68(10-13):981-993.

107. Benagiano G, Bastianelli C, Farris M. Selective progesterone receptor modulators 3: use in oncology, endocrinology and psychiatry. Expert Opin Pharmacother. 2008;9(14):2487-2496.

108. Johanssen S, Allolio B. Mifepristone (RU 486) in Cushing's syndrome. Eur J Endocrinol. 2007;157(5):561-569.

109. Peverelli E, Olgiati L, Locatelli M, et al. The dopamine-somatostatin chimeric compound BIM-23A760 exerts antiproliferative and cytotoxic effects in human non-functioning pituitary tumors by activatin ERK1/2 and p38 pathways. Cancer Lett. 2010;288(2):170-176.

110. Drutel A, Caron P, Archambeaud F. New medical treatments in pituitary adenomas. Ann Endocrinol (Paris). 2008;69 Suppl 1:S16-S28.
Research and Reports in Endocrine Disorders

\section{Publish your work in this journal}

Research and Reports in Endocrine Disorders is an international, peerreviewed, open access journal publishing original research, reports, reviews and commentaries on all areas of endocrinology, endocrine disorders and therapeutic interventions. The manuscript management system is completely online and includes a very quick and fair

\section{Dovepress}

peer-review system. Visit http://www.dovepress.com/testimonials.php to read real quotes from published authors. 